\title{
Variability and Correlation Analysis for Seedling Vigour Traits in Rice (Oryza sativa L.) Genotypes
}

\author{
Bezawada Akshitha $^{1 *}$, P. Senguttuvel ${ }^{2}$, V. Hema Latha ${ }^{1}$, K. N. Yamini ${ }^{3}$, \\ K. Jhansi Rani ${ }^{4}$ and P. Beulah ${ }^{2}$
}

${ }^{1}$ Department of Genetics and Plant Breeding, ${ }^{3}$ Department of Molecular Biology and Biotechnology, ${ }^{4}$ Department of Seed Science and Technology, PJTSAU, College of Agriculture, Rajendranagar, Hyderabad, 500030, Telangana, India

${ }^{2}$ Hybrid Rice, Crop Improvement section, ICAR-Indian Institute of Rice Research, Rajendranagar, Hyderabad, 500030, Telangana, India.

*Corresponding author

\section{A B S T R A C T}

\section{Keywords}

Variability,

Correlation

analysis, Seedling

vigour traits, Rice

Article Info

Accepted:

22 June 2020

Available Online:

10 July 2020
Seedling vigour is an agronomical trait and sign of potential seed germination. It improves the speed, uniformity of the seedlings with good crop stand establishment and grain yield. High vigour is a characteristic of high-quality seed. Therefore the present study was undertaken to assess seedling vigour in 31 rice genotypes and revealed significant genotypic variability among the seedling vigour related traits with highest heritability (90.7\%) for dry weight. High seedling vigour (3406) was expressed in Vandana followed by Bala, AUS 276, Adday sel, N22 and IR 64. High heritability coupled with high GAM was observed for shoot length (83.5 and 52.5) followed by seedling dry weight ( 90.7 and 45.4) mesocotyle length (80.2 and 56.5). Seedling length showed highly significant positive correlation with vigour index (0.98091), shoot length (0.67444), root length $(0.58805)$ and dry weight $(0.37001)$. The promising genotypes were identified for incorporation into breeding programmes. Variability and correlation estimates revealed the selection of characters for identification of high seed vigour.

\section{Introduction}

Rice is one of the most important food crops and the global consumption has seen increase from 437.18 million metric tons in the year
2008 to 486.62 million metric tons in the year 2019 (www.statista.com 2020). It is the only crop in the world that is grown in a most fragile ecosystem and hence second green revolution is possible only if rice research is 
undertaken vigorously and persistently to address specific abiotic and biotic stress problems (Bouman and Tuong, 2001).

Irrigated rice in Asia with 17 million hectares may experience "Physical water scarcity" and 22 million hectares may have "Economic water scarcity" by 2025 (Tuong and Bouman, 2003). Therefore, more efficient use of water is needed in rice production. However, rice production faces a variety of challenges, such as drought, floods and extreme temperatures. These unfavourable factors seriously affect rice yield and sustainable development.

As the first step of rice seedling development, high-quality seed germination can partly overcome adverse environmental impacts and then, directly and indirectly, influence yield (Ellis, 1992). To increase the world's food production in sustainable manner farmers have to use quality seeds.

Good quality and viable seed are required for rapid and synchronous seedling which is prerequisite for successful crop stand establishment, uniform crop growth and finally the yield (Mia and Shamsuddin, 2009). Rice cultivars with strong seedling vigor are desirable for enhancing crop establishment increasing the plant's ability to compete against weeds and subsequently resulting in increased dry matter accumulation and improved grain yield (Lu et al., 2007). The germination capacity and seed vigour are the most important physiological properties of the seed which determine the response to stress conditions.

Seed vigour is important for optimum crop stand establishment and weed competitiveness in rice cropping systems. Several morpho-physiological quantitative traits such as germination rate and seedling growth are associated with seed vigour in rice and performance is generally determined by genotype and modified by the environment (Perry, 1973).

It is an important agronomic seed quality trait that determines the rate of early embryo growth leading to seedling emergence for the development of a photosynthetically independent seedling (Talai and Sen-Mandi, 2010).

Seeds with strong vigour may significantly improve the speed, uniformity of seed germination, the final percentage of germination, field emergence, good crop performance and even high yield under suboptimal conditions (Foolad et al., 2007). Also, high seedling vigour helps the genotypes to suppress the weeds which are a serious problem in rainfed upland and aerobic conditions in tropics and subtropics.

Seed vigour has been known as a comprehensive characteristic affected by many factors, such as the genetic background and environmental factors during seed development and storage stages (Sun et al., 2007) which makes the genetic analysis of seed vigour very difficult.

The cultivars with strong seed vigour are desirable for farmers to get optimum crop stand establishment under sub-optimal field conditions. Loss of vigour in the aged seed of different varieties could reveal the genetic/varietal difference in tolerance to environmental stress thereby providing a parameter for seed vigour trait assessment of different varieties.

Highly vigorous seeds are prerequisites for high field emergence rate and vigorous seedlings (Hampton and Coolbear, 1990). Therefore, the determination of seed vigour is very important before sowing. Keeping in view the importance explained above, the present investigation is being proposed to 
analyze seed vigor and its associated traits among rice genotypes and identify genotypes with high seed vigour.

\section{Materials and Methods}

\section{Plant material and methodology}

Thirty one rice genotypes of different duration and grain types were evaluated for seedling vigour traits in completely randomized design with four replications at Department of Seed Science and Technology, College of Agriculture, PJTSAU, Rajendranagar, Hyderabad. All laboratory observations were recorded in each replication was considered for statistical analysis. The details of genotypes used for the present study was furnished in table 1 .

\section{Estimation of seedling vigour traits}

In order to assess and quantify the genetic variability among the genotypes for the characters under study, the following parameters were estimated as given below. Root and shoot length $(\mathrm{cm})$, seedling length $(\mathrm{cm})$, mesocotyle and coleoptile length $(\mathrm{cm})$, dry weight (g) and vigour index (VI) based on seedling length and on dry weight basis as per Abdul Baki and Anderson (1973).

\section{Estimation of genetic parameters}

Mean, standard error, range were analyzed according to Singh and Chaudhary (1985). Both genotypic and phenotypic coefficients of variability were calculated as the following formula proposed by Singh and Chaudhary (1985). The GCV and PCV values were classified into low (0 - 10), medium (10 - 20) and high (20 and above) as described by Sivasubramanian and Menon (1973). Heritability in broad sense was computed as the ratio of genetic variance to the total phenotypic variance as suggested by Allard (1999) and expressed as percentage.
Heritability estimates were classified into low (0-29), moderate (30-60) and high (61-100) by following Hanson et al., (1956).

Expected genetic advance (GA) and percentage of GA calculated according to Shukla et al., (2006). Genotypic and phenotypic correlation coefficients were calculated and the range of genetic advance as per cent of mean was classified into low (030), medium (30-60) and high (above 60) as suggested by Johnson et al., (1955). The analysis of variance for different characters was carried out using the mean data in order to partition variability due to different sources by following Panse and Sukhatme (1961). All the Statistical analysis was performed using INDOSTAT software. Correlations among the parameters were calculated according to Gomez and Gomez (1983).

\section{Results and Discussion}

The analysis of variance of rice genotypes showed highly significant variation for seedling vigor traits viz., germination per cent, seedling length, shoot length, root length, mesocotyle length, coleoptile length, dry weight and vigour index (Table 2). Highest germination percentage was recorded in AUS 276, Erramallelu, Varalu, Moroberekan and three genotypes showed low viz., AUS 257, Mulai and Satya. Similarly, highest seedling length was observed in Bala, AUS 276, Vandana, Black gora, N22, IR 64 and six genotypes recorded low seedling length (BPT 5204, Varalu, Khao Hlan On, Apo and DRR Dhan 44).

Among all the genotypes N22 and Vandana recorded highest shoot length and six genotypes recorded low shoot length viz., DRR Dhan 44, BPT 5204, MTU-7029, Khao Hlan On, Teqing and RNR-15048. Highest root length was observed in CG 14, Bala, AUS 276, Basmathi 370, MTU-7029, Teqing, IR-64 and six genotypes recorded low root 
length viz., IR 55419-04, Varalu, Adday sel, Apo, Mulai and DRR Dhan 44. Mesocotyle length was high in Mulai, Dular, IR 64 and low mesocotyle length was observed in BPT 5204, Teqing, Bala, Tellahamsa, Satya and UPLRI5. Highest coleoptile length was observed in N22, Dular, IR55414-04 and low coleoptile length was recorded in Teqing, MTU-7029, Bala, Tellahamsa and DRR Dhan 44. Highest dry weight was observed in AUS 276, AUS 171, AUS 257, UPLRI5 and three genotypes viz., IR 6, DRR Dhan 44 and RNR 15048 recorded low dry weight. Vigour index was high in Bala, Adday sel, Vandana, AUS 276, N22, IR 64 and five genotypes were low vigour types (BPT 5204, Khao Hlan On, Apo and DRR Dhan 44).

\section{Analysis of variability parameters}

The results pertaining to genetic variability parameters viz., mean, genotypic coefficient of variability (GCV), phenotypic coefficient of variability $(\mathrm{PCV})$, broad sense heritability $\left(\mathrm{h}^{2}\right)$ and genetic advance as per cent of mean (GAM) for seed vigour characteristics are presented in Table 3. The magnitude of PCV values for all the traits were higher than the corresponding GCV values indicating that these characters may be influenced by the environment.

Genotypic Coefficient of Variability (GCV) and Phenotypic Coefficient of Variability (PCV)

GCV per cent of rice genotypes for various seed vigour traits ranged from $2.56 \%$ to $57.60 \%$. Of all traits four traits showed high GCV (>20 \%) viz., shoot length (21.76\%), root length $(21.36 \%)$, mesocotyle length $(57.60 \%)$ and coleoptile length $(29.67 \%)$ and one trait showed low GCV $(<10 \%) v i z$, germination $\%(2.56 \%)$, rest three traits showed medium GCV (10 - 20\%) viz., seedling length (13.76\%), seedling dry weight $(18.08 \%)$ and vigour index (13.67\%).
Phenotypic Coefficient of Variability of rice genotypes for various seed vigour traits ranged from 3.15 to $64.15 \%$. Of all traits four traits showed high PCV per cent (> $20 \%$ ) viz., shoot length (23.82\%), root length $(24.38 \%)$, mesocotyle length (64.15\%) and coleoptile length (35.14\%) and one trait showed low PCV $(<10 \%)$ viz., germination \% $(3.15 \%)$, rest three traits showed medium PCV (10 - 20\%) viz., seedling length $(14.98 \%)$, seedling dry weight $(18.99 \%)$ and vigour index (15\%).

The magnitude of variance was revealed by genotypic and phenotypic coefficients of variation (GCV and PCV). High GCV and PCV were observed for shoot length $(21.76 \%$, $23.82 \%)$, root length $(21.36 \%, 24.38 \%)$, mesocotyle length $(57.60 \%, 64.15 \%)$ and coleoptile length $(29.67 \%, 35.14 \%)$ and moderate for seedling length $(13.76 \%$, $14.98 \%)$, seedling dry weight $(18.08 \%$, $18.99 \%)$ and vigour index $(13.67 \%, 15 \%)$. But, it was low with respect to germination \% $(2.56 \%, 3.15 \%)$.

\section{Heritability}

The characters studied in the present investigation expressed high heritability estimates ranging from 90.7- 66.2 per cent. Among the characters, highest heritability was recorded for seedling dry weight $(90.7$ $\%)$ followed by seedling length (84.4\%), shoot length $(83.5 \%)$, vigour index $(82.8 \%)$, mesocotyle length $(80.2 \%)$, coleoptile length $(71.3 \%)$, root length $(76.8 \%)$ and germination per cent $(66.2 \%)$.

\section{Genetic advance as per cent of mean (GAM)}

The genetic advance expressed as percentage of mean values ranged from 5.5 to 66.1 per cent. The characters mesocotyle length (56.5\%), coleoptile length (66.1\%) recorded higher magnitude of GAM. The characters 
viz., shoot length $(52.5 \%)$ root length (49.4 $\%)$, and seedling dry weight $(45.4 \%)$ recorded moderate GAM, seedling length $(33.3 \%)$ and seedling vigor $(32.7 \%)$ recorded low magnitudes of GAM, while germination percentage $(5.5 \%)$ recorded extremely low magnitudes of GAM.

In the present investigation, high heritability coupled with high GAM was observed for shoot length (83.5 and 52.5) followed by seedling dry weight (90.7 and 45.4) mesocotyle length (80.2 and 56.5) Fig.1. In general, the traits in that had high genotypic coefficient of variation (GCV) and phenotypic coefficient of variation (PCV) followed by high heritability and genetic advance Table 3; suggested selection may be practiced for improvement of these traits.

Table.1 Genotypes used as experimental material under study

\begin{tabular}{|c|c|c|}
\hline S.No. & Genotype & Parentage \\
\hline 1. & CG-14 & Oryza. Glaberrima \\
\hline 2. & Bala & $\mathrm{N} 22 / \mathrm{TN}-1$ \\
\hline 3. & AUS 276 & land race \\
\hline 4. & Basmati 370 & Pureline selection from local basmati land race \\
\hline 5. & IR 55419-04 & - \\
\hline 6. & Erramallelu & BC-5-55 x W-12708 \\
\hline 7. & BPT-5204 & GEB 24 / TN1 // Mahsuri \\
\hline 8. & Varalu & WGL 20471 / CR 544-1-2 \\
\hline 9. & MTU 7029 & Vasistha / Mahsuri \\
\hline 10. & Teqing & - \\
\hline 11. & AUS 171 & land race \\
\hline 12. & AUS 257 & land race \\
\hline 13. & Palawan & land race \\
\hline 14. & Khao Hlan On & land race \\
\hline 15. & UPLRI5 & - \\
\hline 16. & Moroberekan & land race \\
\hline 17. & Vandana & C 22 / Kalakeri \\
\hline 18. & IR 6 & - \\
\hline 19. & B644F-MR-6 & - \\
\hline 20. & Adday sel & land race \\
\hline 21. & Dular & land race \\
\hline 22. & Apo & UPL RI 5/IR12979-24-1 \\
\hline 23. & Black gora & land race \\
\hline 24. & Mulai & land race \\
\hline 25. & $\mathrm{~N} 22$ & Selection from Rajbhog \\
\hline 26. & IR-64 & IR 5657-33-2-1 / IR 2061-465-1-5-5 \\
\hline 27. & DRR-Dhan 44 & IR 71700-247-1-1-2 / IR 03L 120 \\
\hline 28. & Satya & Tellahamsa / Rasi \\
\hline 29. & RNR- 15048 & MTU1010/WGL3844 \\
\hline 30. & Tellahamsa & HR 12 / TN1 \\
\hline 31. & Cypress & L-202/Lemont \\
\hline
\end{tabular}


Table.2 ANOVA for seedling vigour related traits among rice genotypes

\begin{tabular}{|c|c|c|c|c|c|c|c|c|c|}
\hline $\begin{array}{l}\text { Source of } \\
\text { variance }\end{array}$ & df & $\begin{array}{l}\text { Seedling } \\
\text { length(cm) }\end{array}$ & $\begin{array}{l}\text { Shoot } \\
\text { length(cm) }\end{array}$ & $\begin{array}{l}\text { Root } \\
\text { length(cm) }(\mathbf{c m})\end{array}$ & $\begin{array}{l}\text { Mesocotyle } \\
\text { length(cm) }\end{array}$ & $\begin{array}{l}\text { Coleoptile } \\
\text { length(cm) }\end{array}$ & $\begin{array}{l}\text { Germination } \\
(\boldsymbol{\%})\end{array}$ & $\begin{array}{l}\text { Dry } \\
\text { weight(g) }\end{array}$ & Vigour index \\
\hline Treatments & $\mathbf{3 0}$ & $147.60 * *$ & $71.55 * *$ & $47.00 * *$ & $9.17 * *$ & $12.00 * *$ & $37.146 * *$ & $0.012 * *$ & $709287.300 * *$ \\
\hline Error & $\mathbf{9 3}$ & 1.92 & 0.51 & 0.41 & 0.03 & 0.10 & 2.69 & 0.001 & 18186.33 \\
\hline $\mathbf{C V}(\boldsymbol{\%})$ & & 5.42 & 5.32 & 5.19 & 7.02 & 7.00 & 1.77 & 5.89 & 5.47 \\
\hline
\end{tabular}

** = Significant at $1 \% \mathrm{t}$ value

Table.3 Mean, range and genetic parameters for seedling vigour traits among rice genotypes

\begin{tabular}{|c|c|c|c|c|c|c|c|c|}
\hline S.No. & Character & Mean & Minimum & Maximum & GCV & PCV & Heritability & GAM \\
\hline 1. & Germination (\%) & 95.7 & 88.75 & 99.75 & 2.56 & 3.15 & 66.2 & 5.50 \\
\hline 2. & Seedling length $(\mathrm{cm})$ & 26.6 & 16.5 & 35.5 & 13.76 & 14.98 & 84.4 & 33.3 \\
\hline 3. & Shoot length $(\mathrm{cm})$ & 14 & 8.1 & 21.7 & 21.76 & 23.82 & 83.5 & 52.5 \\
\hline 4. & Root length $(\mathrm{cm})$ & 12.7 & 8 & 17.6 & 21.36 & 24.38 & 76.8 & 49.4 \\
\hline 5. & Mesocotyle length $(\mathrm{cm})$ & 2.3 & 0.5 & 5.6 & 57.60 & 64.15 & 80.2 & 56.5 \\
\hline 6. & Coleoptile length $(\mathrm{cm})$ & 4.7 & 2.7 & 8.2 & 29.67 & 35.14 & 71.3 & 66.1 \\
\hline 7. & Dry weight (g) & 0.13 & 0.085 & 0.175 & 18.08 & 18.99 & 90.7 & 45.4 \\
\hline 8. & Vigour Index & 2549 & 1600 & 3406 & 13.64 & 15.00 & 82.8 & 32.7 \\
\hline
\end{tabular}


Table.4 Correlation among seedling vigour traits in rice genotypes

\begin{tabular}{|c|c|c|c|c|c|c|c|c|c|}
\hline Character & $\begin{array}{c}\text { Germination } \\
\%\end{array}$ & $\begin{array}{l}\text { Seedling } \\
\text { length } \\
(\mathrm{cm})\end{array}$ & $\begin{array}{c}\text { Shoot } \\
\text { length }(\mathrm{cm})\end{array}$ & $\begin{array}{c}\text { Root } \\
\text { length }(\mathrm{cm})\end{array}$ & $\begin{array}{l}\text { Mesocotyle } \\
\text { length }(\mathrm{cm})\end{array}$ & $\begin{array}{l}\text { Coleoptile } \\
\text { length }(\mathrm{cm})\end{array}$ & $\begin{array}{c}\text { Dry } \\
\text { weight }(g)\end{array}$ & $\begin{array}{c}\text { Field } \\
\text { Emergence }\end{array}$ & $\begin{array}{l}\text { Vigour } \\
\text { index }\end{array}$ \\
\hline $\begin{array}{l}\text { Germination } \\
\%\end{array}$ & 1.00000 & 0.18186 & -0.12833 & -0.10072 & -0.12428 & -0.15372 & -0.19439 & 0.08080 & 0.01239 \\
\hline $\begin{array}{l}\text { Seedling } \\
\text { length }(\mathrm{cm})\end{array}$ & & 1.00000 & $0.67444 * * *$ & $\begin{array}{c}0.58805 \\
* * *\end{array}$ & 0.26128 & 0.21493 & $0.37001 *$ & -0.05174 & $0.98091 * * *$ \\
\hline $\begin{array}{l}\text { Shoot } \\
\text { length }(\mathrm{cm})\end{array}$ & & & 1.00000 & -0.20059 & $\begin{array}{c}0.62625 \\
* * *\end{array}$ & $\begin{array}{c}0.70518 \\
* * *\end{array}$ & 0.27406 & 0.27671 & $0.65875 * * *$ \\
\hline $\begin{array}{l}\text { Root } \\
\text { length(cm) }\end{array}$ & & & & 1.00000 & -0.33935 & $\begin{array}{c}-0.48733 \\
* *\end{array}$ & 0.19072 & $-0.37178 *$ & $0.57990 * * *$ \\
\hline $\begin{array}{l}\text { Mesocotyle } \\
\text { length }(\mathrm{cm})\end{array}$ & & & & & 1.00000 & $\begin{array}{c}0.92119 \\
* * *\end{array}$ & 0.04154 & $0.40227 *$ & 0.24125 \\
\hline $\begin{array}{l}\text { Coleoptile } \\
\text { length }(\mathrm{cm})\end{array}$ & & & & & & 1.00000 & 0.08931 & $0.41968 *$ & 0.18675 \\
\hline Dry weight(g) & & & & & & & 1.00000 & -0.13822 & 0.34108 \\
\hline $\begin{array}{l}\text { Field } \\
\text { Emergence }\end{array}$ & & & & & & & & 1.00000 & -0.03546 \\
\hline Vigour index & & & & & & & & & 1.00000 \\
\hline
\end{tabular}

*** significant at $0.001 \%$ level ; ** significant at $0.01 \%$ level ; * significant at $0.05 \%$ level 
Fig.1 Components of variance of seedling vigour related traits in rice genotypes

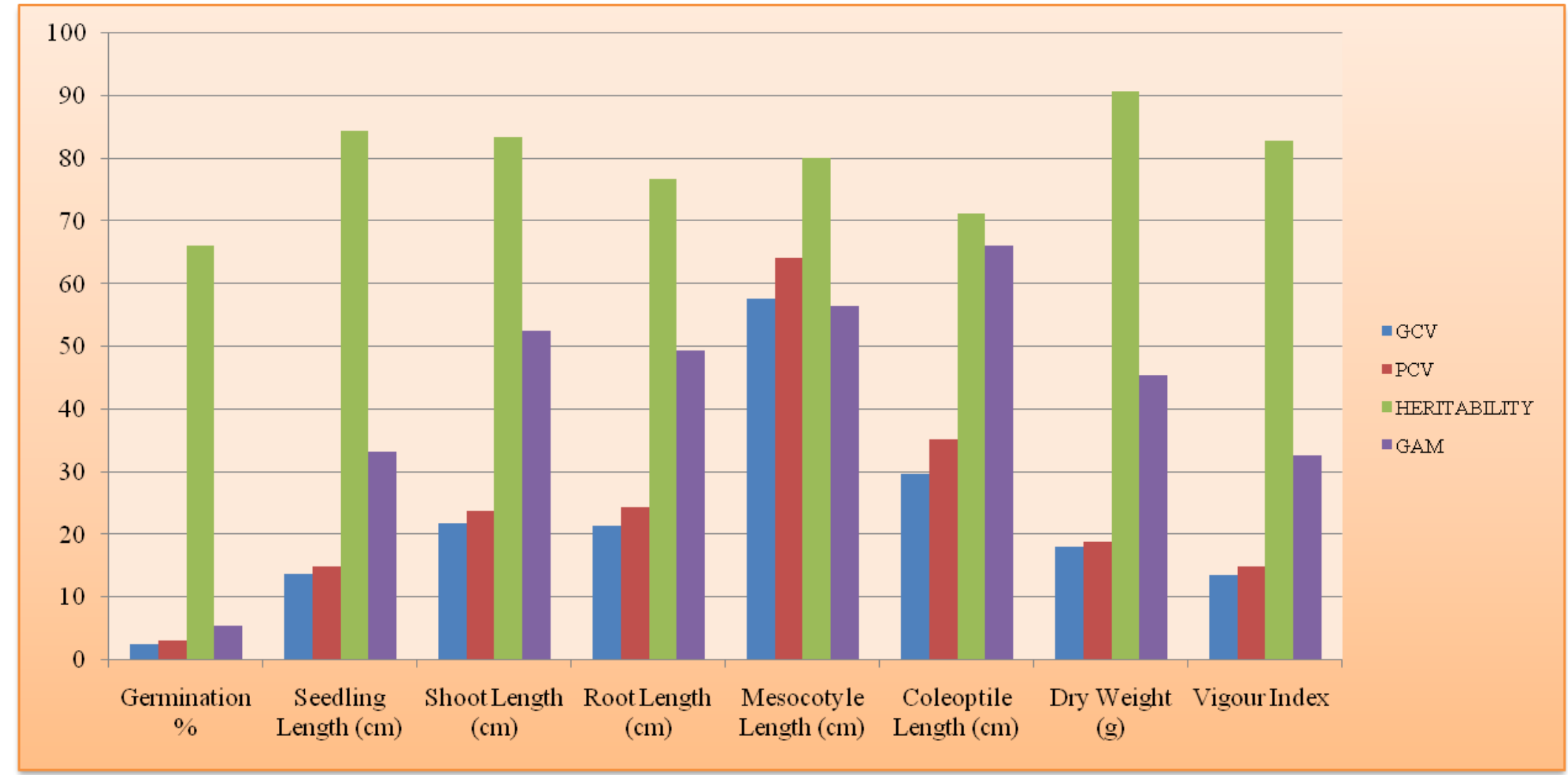

GCV=Genotypic Coefficient of Variability, PCV= Phenotypic Coefficient of Variability

$\mathrm{GAM}=$ Genetic Advance as per cent of Mean 


\section{Correlations}

Correlation between traits is of interest to determine whether selection for one trait will have an effect on another. Simple correlation coefficient from the combined data was shown in Table 4. Correlation coefficient determined over the 31 rice genotypes for eight seedling vigour traits revealed significant correlation among germination per cent, seedling length, shoot length, root length, mesocotyle length, coleoptile length, dry weight and vigour index. Seedling length showed highly significant positive correlation with vigour index (0.98091), shoot length (0.67444), root length (0.58805) and dry weight (0.37001). Shoot length showed significant positive correlation with mesocotyle length (0.62625), coleoptile length (0.70518) and vigour index (0.65875). Root length showed significant negative correlation with coleoptile length $(-0.48733)$ and significant positive correlation with vigour index (0.57990). Mesocotyle length showed significant correlation with coleoptile length (0.92119).

Seedling vigor is an important trait for better crop establishment in direct seeded rice and associated traits are quantitatively inherited (Zhang, 1995). Based on seed vigour analysis among the 31 genotypes, five genotypes were classified as high vigour (Bala, Vandana, AUS 276, Adday sel, N22 and IR 64); five genotypes were low vigour types (BPT 5204, Khao Hlan On, Apo and DRR Dhan 44) and rest twenty one genotypes as medium vigour genotypes. Similar type of results were obtained by Sujay (2007) for 100-seed weight, germination, shoot length, root length, seedling dry weight and seed vigor index II. Cui et al., (2002a) determined significant correlation among the five seedling vigor traits viz., germination rate, total dry weight, shoot dry weight, root dry weight and maximum root length. Variation in the performance of the varieties during the vigour test implied that some of the varieties with low vigour will lose their viability quicker than those with high vigour when stored under the same conditions. Mahadevappa and Nandisha (1987), Richman et al., (2006), Black and Halmer (2006) and ISTA (2007) and had earlier reported that seeds with low vigour lost their viability quickly than those with much higher vigour when stored under the same condition. IRRI (2009) reported that seeds low in vigour produce weak seedlings that are susceptible to environmental stresses while those with high vigour provide for early and uniform stands which give the growing seedlings good resistance against various environmental stresses.

Tejaswi (2012) reported that seedling vigour index varied significantly among the genotypes. Highest seedling vigour index was noticed in Vandana (2187) and the lowest in DRR Dhan 38 (557). Seedling vigour has therefore been defined by Lee et al., (1986) as a quality factor that determines the potential for rapid germination and fast seedling growth under field conditions and this potential varies in accordance with genetic and environmental backgrounds. Seedling length showed highly significant positive correlation with vigour index, shoot length, root length and dry weight. Significant correlations among the five seedling vigour traits (germination rate, total dry weight, shoot dry weight, root dry weight and maximum root length) were observed by Cui et al., (2002b) and reported that the correlations among the five physiological parameters were relatively weak compared with the correlations among the seedling vigour traits.

\section{Acknowledgments}

This study was supported by the Indian Institute of Research (IIRR) and Department of Seed Science and Technology. 


\section{References}

Abdul Baki, A.A and Anderson, J.D. 1973. Vigour determination in soybean seed by multiple criteria. Crop Science. 13: 630-633.

Allard, R.W. 1999. Principles of plant breeding. ( $2^{\text {nd }}$ Edition). John Wiley and Sons, New York, USA.

Black, M. H and Halmer, P. 2006. The encyclopedia of seeds: science, technology and uses. Wallingford, UK. 224.

Bouman, B.A.M and Tuong, T.P. 2001. Field water management to save water and increase its productivity in irrigated lowland rice. Agriculture Water Management. 49 (1): 11-30.

Cui, K., Peng, S., Xing, Y., Xu, C., Yu, S and Zhang, Q. 2002a. Molecular dissection of seedling-vigor and associated physiological traits in rice. Theoretical and Applied genetics. 105 (5): 745-753.

Cui, K.H., Peng, S.B., Xing, Y.Z., Yu, S.B and $\mathrm{Xu}, \mathrm{C.G}$ 2002b. Molecular dissection of relationship between seedling characteristics and seed size in rice. Acta Botanica Sinica. 44: 702-707.

Ellis, R.H. 1992. Seed and seedling vigour in relation to crop growth and yield. Plant Growth Regulation. 11 (3): 249-255.

Foolad, M.R., Subbiah, P and Zhang, L. 2007. Common QTL affect the rate of tomato seed germination under different stress and nonstress conditions. International journal of plant genomics. 2007.

Gomez, K. A., and Gomez, A. A.1983. Statistical procedure for agricultural research. 2nd Edition. John Wiley and sons, Inc. Publishers, Canada. 363-366.

Hampton, J.G and Coolbear, P. 1990. Potential versus actual seed performance - Can vigour provides an answer. Seed Science and Technology. 18 (2): 215- 228.

Hanson, C.H., Robinson, H.G and Comstock,
R.E. 1956. Biometrical studies of yield in segregating populations of Korean Lespediza. Agronomy Journal. 48: 268272.

https://www.statista.com/statistics/255977/tot al-global-rice-consumption/

IRRI. 2009. Farm data-Rice ecosystems, 30. Distribution of rice crop area, by environment, 2004-2006. In: IRRI (eds.) - IRRI World Rice Statistics. IRRI, Los Baños, Phillipines. http://beta.irri.org/statistics.

ISTA. 2007. International Rules for Seed Testing. Published by International Seed Testing Association, Zurich, Switzerland.

Johnson, H.W., Robinson, H.F and Comstock, R.E. 1955. Estimates of genetic and environmental variability in soybeans. Agronomy Journal. 47: 314-318.

Lee, C.C., Li, C.C and Sung, F.J.M. 1986. Physiological and genetic studies on seedling vigour in rice (Oryza sativa L.)II. Inheritance of alpha-amylase activity and seedling vigour in rice. Journal of Agricultural Association of China. 135: 17-24.

Lu, X.L., Niu, A.L., Cai, H.Y., Zhao, Y., Liu, J.W., Zhu, Y.G and Zhang, Z.H. 2007. Genetic dissection of seedling and early vigor in a recombinant inbred line population of rice. Plant Science. 172 (2): 212-220.

Mahadevappa, M. and Nandisha, B. S. 1987. A review of the status of genetic analysis of characters important in harvest, post-harvest and seed technology of rice (Oryza sativa L.) in southern India. Seed science and Technology. 15: 585-591.

Mia, M.A.B and Shamsuddin, Z.H. 2009. Enhanced emergence and vigor seedling production of rice through growth promoting bacterial inoculation. Research Journal of Seed Science. 2 (4): 96-104. 
Panse, V. G. and Sukhatme.P. V. 1961. Indian Council of Agricultural Research Publication, New Delhi. Statistical Methods for Agricultural Workers.359.

Perry, D.A. 1973. Seed vigour and field establishment. Horticulture Abstracts. 42: 334-342.

Richman, J.F., Bell, M and Shires, D. 2006. Seed http//www.knowledgebank.irri.org.

Shukla, S., Bhargava, A., Chatterjee, A., Srivastava, J., Singh, N and Singh, S.P. 2006. Mineral profile and variability in vegetable amaranth (Amaranthus tricolor). Plant Foods for Human Nutrition. 61 (1): 21-26.

Singh, R.K and Chaudhary, B.D. 1985. Biometrical methods in quantitative genetic analysis. Kalyani Publisher, New Delhi, India.

Sivasubramanian, S and Menon, M. 1973. Heterosis and inbreeding depression in rice. Madras Agricultural Journal. 60: 1139.

Sujay, V. 2007. Evaluation of early vigour related traits in upland rice (Oryza sativa L.). M. Sc. (Ag) Thesis.
University of Agricultural Sciences, Dharwad, India

Sun, Q., Wang, J.H and Sun, B.Q 2007. Advances on seed vigour physiological and genetic mechanisms. Agriculture Science in China. 6 (9): 1060-1066.

Talai, S and Sen-Mandi, S. 2010. Seed vigour-related DNA marker in rice shows homology with acetyl CoA carboxylase gene. Acta physiologiae plantarum. 32 (1): 153-167.

Tejaswi, N.L. 2012. Identification of molecular markers for seedling vigour traits in rice (Oryza sativa L.) genotypes. M.Sc Thesis. Acharya N.G Ranga Agricultural University, Hyderabad, India.

Tuong, T.P., Bouman, B.A.M. 2003. Rice production in water scarce environments. Water productivity in agriculture; limits and opportunities for improvement.

Zhang, H. B. 1995. BAC workshop manual. Southern crop improvement facility, Texas $A$ and $M$ University, College Station. 36-37.

\section{How to cite this article:}

Bezawada Akshitha, P. Senguttuvel, V. Hema Latha, K. N. Yamini, K. Jhansi Rani and Beulah, P. 2020. Variability and Correlation Analysis for Seedling Vigour Traits in Rice (Oryza sativa L.) Genotypes. Int.J.Curr.Microbiol.App.Sci. 9(07): 2877-2887. doi: https://doi.org/10.20546/ijcmas.2020.907.341 